\title{
Measurements of HONO during BAQS-Met
}

\author{
J. J. B. Wentzell ${ }^{1,2, *}$, C. L. Schiller ${ }^{1,2,{ }^{* *}}$, and G. W. Harris ${ }^{1,2}$ \\ ${ }^{1}$ Department of Chemistry, York University, Toronto, Ontario, Canada \\ ${ }^{2}$ Centre for Atmospheric Chemistry, York University, Toronto, Ontario, Canada \\ *now at: Environment Canada, Science and Technology Branch, Toronto, ON, Canada \\ *** now at: Environment Canada, Science and Technology Branch, Vancouver, BC, Canada
}

Received: 30 April 2010 - Published in Atmos. Chem. Phys. Discuss.: 21 June 2010

Revised: 29 November 2010 - Accepted: 3 December 2010 - Published: 23 December 2010

\begin{abstract}
Measurements of nitrous acid (HONO) were performed as part of the 2007 Border Air Quality and Meteorology Study (BAQS-Met) at the Harrow, Ontario, Canada supersite between 20 June and 10 July 2007. Nitrous acid is an important precursor of the hydroxyl radical and understanding its chemistry is important to understanding daytime oxidation chemistry. The HONO measurements were made using a custom built Long Path Absorption Photometer (LOPAP). The goal of this work was to shed light on sources of daytime HONO in the border region. During the course of the campaign HONO mixing ratios consistently exceeded expected daytime values by more than a factor of 6 . Mean daytime mixing ratios of $61 \mathrm{pptv}$ were observed. While HONO decay began at sunrise, minimum $\mathrm{HONO}$ values were measured during the late afternoon. There was little difference between the daytime (mean $=1.5 \%)$ and night-time (mean $=1.7 \%$ ) ratios of $\mathrm{HONO} / \mathrm{NO}_{2}$, thus there was a very strong daytime source of HONO which is consistent with other recent studies. Correlations of daytime HONO production with a variety of chemical and meteorological parameters indicate that production is dependent on UV radiation, $\mathrm{NO}_{2}$ and water vapour but is not consistent with a simple gas phase process. Apparent rate constants for the production of $\mathrm{HONO}$ from photolyticaly excited $\mathrm{NO}_{2}$ and water vapour vary from $2.8-7.8 \times 10^{-13} \mathrm{~cm}^{3} \mathrm{molec}^{-1} \mathrm{~s}^{-1}$, during the campaign. These results appear to be consistent with the heterogeneous conversion of $\mathrm{NO}_{2}$ enhanced by photo-excitation.
\end{abstract}

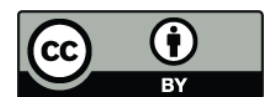

Correspondence to: G. W. Harris (gharris@yorku.ca)

\section{Introduction}

Nitrous acid plays an important role in the atmospheric chemistry of the troposphere. Typically it follows a diurnal cycle where the mixing ratio of HONO increases at night and HONO is destroyed in the morning by photolysis (Reaction R1). The photolysis results in the production of the hydroxyl radical and may be the dominant early morning source of $\mathrm{OH}$ (Alicke et al., 2002; Alicke et al., 2003; Harris et al., 1982; Platt et al., 1980).

$\mathrm{HONO}+h v(300-400 \mathrm{~nm}) \rightarrow \mathrm{OH}+\mathrm{NO}$

In addition to $\mathrm{HONO}$ photolysis, $\mathrm{OH}$ can be produced by photolysis of ozone and formaldehyde (followed by the reaction of $\mathrm{HO}_{2}$ with $\mathrm{NO}$ ). $\mathrm{OH}$ is also a secondary product of the ozonolysis of alkenes. Nitrous acid's contribution to the $\mathrm{OH}$ budget affects photochemistry in both urban and rural areas. In urban environments HONO mixing ratios can reach several parts per billion (ppbv) (Harris et al., 1982), while in rural or remote environments 10's to 100's of parts per trillion (pptv) appear to be common (Acker et al., 2006). A study of HONO in a forest in 2005 found that HONO contributed $33 \%$ of the integrated daytime OH budget (Kleffmann et al., 2005), surpassing all other $\mathrm{OH}$ formation pathways.

In recent years there has been great interest in photolytic pathways for $\mathrm{HONO}$ formation. Nitrous acid production has been observed from photo-enhanced reduction of $\mathrm{NO}_{2}$ on humic acid-like compounds (Stemmler et al., 2006) in addition to other organic surfaces (George et al., 2005). Production occurred when these surfaces were irradiated with light between 300-420 nm under humid condition. Conversion efficiencies of $\mathrm{NO}_{2}$ to $\mathrm{HONO}$ between 50 and close to $100 \%$ have been reported (Stemmler et al., 2006). Photolysis of ortho-nitrophenols has also been suggested as a

Published by Copernicus Publications on behalf of the European Geosciences Union. 


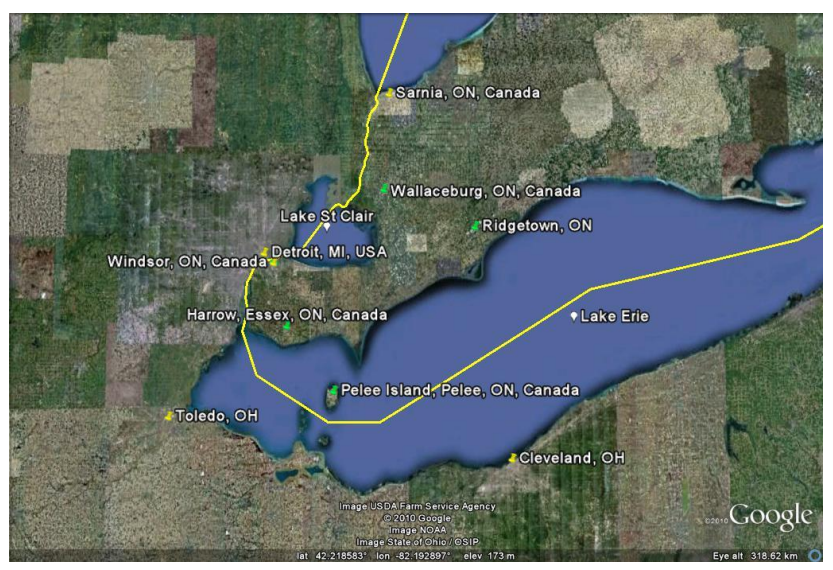

Fig. 1. Map South Western Ontario showing BAQS-Met measurement sites in green and industrial towns in the Lake Erie area.

relevant daytime production mechamism in the urban atmosphere (Bejan et al., 2006). An excellent overview of daytime HONO chemistry which examines daytime sources and sinks has been published (Kleffmann, 2007).

Here we present results HONO measurement results from the Border Air Quality Meteorology study (BAQS-Met) at the Harrow, Ontario, Canada supersite. The mixing ratios observed were higher than anticipated during the daytime hours. Daytime HONO production rates appear to be consistent with a heterogeneous sunlight enhanced source.

\section{Experimental}

\subsection{Site description}

During the summer of 2007 the Long Path absorption Photometer (LOPAP) was deployed as part of the Border Air Quality and Meteorological Study (BAQS-Met) at the Harrow, Ontario (Essex County) supersite (42.03418, -82.9174) (Fig. 1). BAQS-Met was a major collaborative study designed to help understand the effects of the transborder flow of pollutants, lake effects and gas/particle processing that occur in Southern Ontario. There were three Supersite locations during the study; Harrow, Ontario, Ridgetown, Ontario and Bear Creek, Ontario (southwest of Wallaceburg, Ontario). Measurements were also performed at two smaller sites, one on Pelee Island, the other in Windsor, Ontario. Harrow is in close proximity to the metropolitan Detroit, Michigan and Windsor, Ontario areas. It is a semi rural location which is frequently affected by emissions from Detroit/Windsor as well from the Ohio Valley to the South and the Sarnia, Ontario region to the North.

\subsection{Long Path Absorption Photometer}

Nitrous acid was measured using a custom built Long Path Absorption Photometer (LOPAP) located in the middle of a grass field on the grounds of Agriculture and Agri-Food Canada's Greenhouse and Processing Crops Research Centre. The LOPAP technique has been described in detail elsewhere, (Heland et al., 2001; Kleffmann et al., 2002) and is therefore only briefly described here. The instrument is composed of two sections, a sampling unit and a detection unit. The sampling section is composed of two glass coils $(17 \mathrm{~cm}$ of glass each) in series, one for each channel. A $0.06 \mathrm{M}$ sulfanilamide (SA) solution is pumped to and from each coil at a flow rate of $0.4 \mathrm{~mL} \mathrm{~min}^{-1}$. Air is pulled through the coils at a flow rate of $1 \mathrm{~L} \mathrm{~min}^{-1}$. No liquid is carried from channel 1 to channel 2. The liquid from each coil is pumped to debubblers where any small air bubbles are separated from the liquid. The solutions are then mixed with a $0.2 \mathrm{mM}$ solution of 1-naphtyl ethylennediammine dihydrohloride (NED), where an azo dye is formed from sampled $\mathrm{NO}_{2}^{-}$. The azo dye is pumped from each channel into separate liquid core waveguides. The waveguides used were $2 \mathrm{~m}$ in length and purchased from World Precision Instruments (WPI LWCC, 2200). The dye can then be measured by photometry using a UV/VIS light source and a spectrometer. The light source used was a Tungsten Halogen lamp (LS-1, Ocean Optics) while the detector was a 2-channel mini-CCD spectrometer (Ocean Optics S2000). All solutions are delivered using an 8-channel peristaltic pump (Ismatec). From gas phase calibrations it was determined that nitrous acid is sampled nearly quantitatively in the first channel (99\%). Other slightly soluble species are sampled in both channels and the resulting interference in the 1st channel is removed by subtraction of the signal in the 2 nd channel. Interferences have been discussed at length by others (Kleffmann et al., 2002). A $3 \sigma$ detection limit of 5 pptv was determined for a 5 min measurement with the LOPAP. At the Harrow site the LOPAP was installed in a trailer that contained other standard instruments for measuring gas and aerosol mixing ratios. The sampling coil was mounted outside of the trailer. During the campaign the instrument was regularly calibrated using sodium nitrite $\left(\mathrm{NaNO}_{2}\right)$ standard solutions.

\subsection{Other measurements}

Other concurrent measurements were made at the site including ozone based on UV-absorption $\mathrm{NO}_{\mathrm{x}}$ using a chemiluminesence monitor. The $\mathrm{NO}_{\mathrm{x}}$ measurements were used to estimate $\mathrm{NO}_{2}$ as $\left(\mathrm{NO}_{\mathrm{x}}-\mathrm{NO}\right)$. It is known the the " $\mathrm{NO}_{\mathrm{x}}$ " measured by the Thermoscientific analyser consists of $\mathrm{NO}_{2}$ plus contributions from other $\mathrm{NO}_{\mathrm{y}}$ species and is likely overestimated. Meteorological parameters such as temperature, relative humidity, wind speed, wind direction, and barometric pressure were also recorded. HONO photolysis frequencies $\left(J_{\mathrm{HONO}}\right)$ were estimated from measurements using an Eppley total UV 
radiometer on the roof of the trailer. The estimation was based on a previously quantified relationship between the UV Radiometer and a HONO Chemical Actinometer (Wall et al., 2006). In that study a Heraeus Amersil Electrically Fused quartz cell was used as the photolysis cell on the roof of a building in Toronto, Ontario. The actinometer was set up so that known amounts of HONO could be sent through the cell to a high pressure liquid chromatograph (HPLC) detection unit or diverted directly to the HPLC detection unit. The measured difference was used to calculate values of $J_{\mathrm{HONO}}$. The estimated error in $J_{\mathrm{HONO}}$ values under clear sky conditions was $11 \%$ at sunrise and $4 \%$ at solar noon during the summer months. Based on the error in the original $J_{\mathrm{HONO}}$ measurement (from clear sky conditions) $J_{\mathrm{HONO}}$ values during BAQS-Met are estimated to be accurate within $20 \%$. A list of instruments used is shown in Table 1.

\section{Measurements of HONO at Harrow}

Nitrous acid measurements were made between 20 June and 10 July 2007. During many nights of the campaign HONO mixing ratios built up over the course of the night and began to decrease in the morning with the onset of photolysis. However, minimum HONO mixing ratios were not reached until the late afternoon and rarely decreased below detection limits ( $5 \mathrm{pptv}$ ). The mean daytime mixing ratio of HONO was $61 \mathrm{pptv}$ (maximum $=473 \mathrm{pptv})$, while the mean nighttime value was $102 \mathrm{pptv}$, (maximum $=376 \mathrm{pptv})$. The NO observed was almost always a small fraction of $\mathrm{NO}_{\mathrm{x}}$. As noted the molybdenum converter in the chemiluminescence monitor can partially reduce other $\mathrm{NO}_{y}$ components as well as $\mathrm{NO}_{2}$. The detection limit for $\mathrm{NO}$ was $1 \mathrm{ppbv}$.

During the period of 21 to 27 June (Fig. 2), HONO mixing ratios consistently reached $300 \mathrm{pptv}$ or more during the night-time. The increases in HONO during this period were matched by increases in $\mathrm{NO}_{2}$ mixing ratio, (as defined). As the sun rose mixing ratios would show an initial sharp decrease in the early morning continuing more slowly throughout the day until minimum mixing ratios were reached generally late in the afternoon. As the sun set ( 21:00 EST), and wind speeds decreased, $\mathrm{HONO}$ and $\mathrm{NO}_{2}$ mixing ratio would increase. Nitrous acid mixing ratios were consistently lower between 28 June and 6 July (Fig. 3). Winds during this time were usually from the North East bringing pollution from the Sarnia, Ontario area.

On the night of 23/24 June HONO mixing ratios reached $200 \mathrm{pptv}$ and remained roughly constant for the duration of the night. Since wind speeds were low that night it is not obvious why HONO mixing ratios did not rise for the duration of the night until the breakup of the boundary layer and onset of photolysis in the morning hours. Such behaviour has been observed before (Stutz et al., 2002) and it was shown that $\mathrm{NO}_{2}$ mixing ratios greater than $10 \mathrm{ppbv}$ lead to HONO formation (positive HONO gradients) over grass

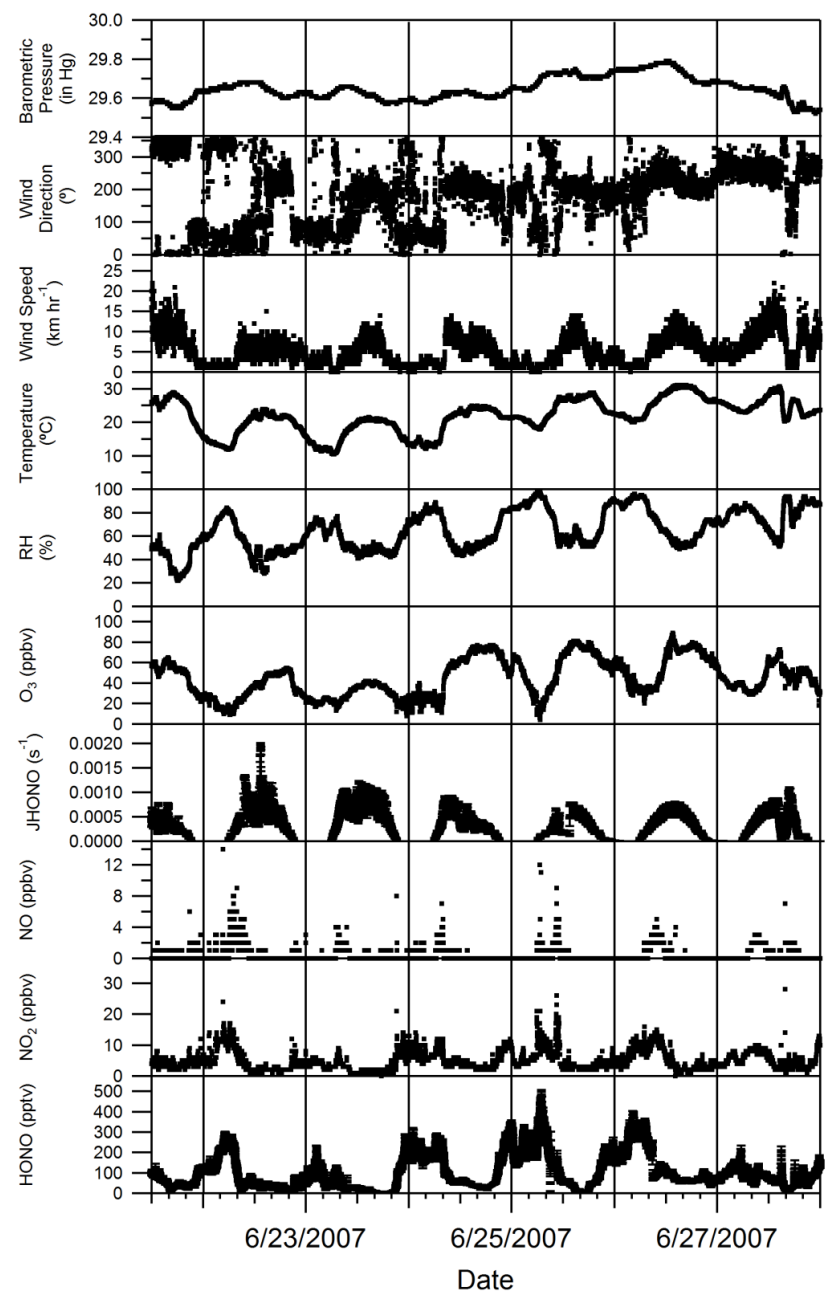

Fig. 2. Time series of the measurements of $\mathrm{HONO}, \mathrm{NO}_{2}, \mathrm{NO}$, $J_{\mathrm{HONO}}, \mathrm{O}_{3}$, relative humidity, temperature, wind speed, wind direction and barometric pressure at the Harrow measurement site from 21-27 June 2007.

in Milan. A compensation point in the $\mathrm{HONO} / \mathrm{NO}_{2}$ ratio of $3 \%$ was determined where $\mathrm{HONO}$ would begin to deposit on the grass surface under stable meteorological conditions. It was believed that $\mathrm{NO}_{2}$ was hydrolyzing on the damp grass to produce the measured HONO. This is consistent with our HONO/NO $/ \mathrm{N}_{2}$ ratios observed on the night of the 23/24 with $\mathrm{HONO} / \mathrm{NO}_{2}$ ratios between $2-4 \%$. $\mathrm{NO}_{2}$ mixing ratios were near 10 ppbv for much of this night it is likely that deposition was partly controlling of the relatively constant HONO mixing ratios observed.

During the night of 28/29 June $\mathrm{HONO}$ and $\mathrm{NO}_{2}$ were highly correlated (Fig. 4). Winds were consistently from the North East and decreased from 10 to $<5 \mathrm{~km} \mathrm{hr}^{-1}$ in the early part of the evening. Two decreases in mixing ratio of $\mathrm{HONO}, \mathrm{NO}_{2}$ and $\mathrm{NO}$ were observed, the first minima occurred at 01:00 and the second occurred at 04:00 (both local time), and corresponded with increases in $\mathrm{O}_{3}$ mixing ratio. 
Table 1. List of Instrumentation at Harrow Supersite.

\begin{tabular}{lll}
\hline Species & Instrument & Affiliation \\
\hline $\mathrm{HONO}$ & LOPAP & York University \\
$\mathrm{NO}_{\mathrm{x}}$ & $\mathrm{NO}_{\mathrm{x}}$ analyser (Thermo-Scientific) & Ontario Ministry of the Environment \\
$\mathrm{O}_{3}$ & $\mathrm{O}_{3}$ monitor (Thermo-Scientific) & Ontario Ministry of the Environment \\
$J_{\mathrm{HONO}}$ (estimate) & Total UV Radiometer (Eppley Labs) & York University \\
Particle Size Distribution & FMPS (TSI) & University of Toronto \\
\hline
\end{tabular}

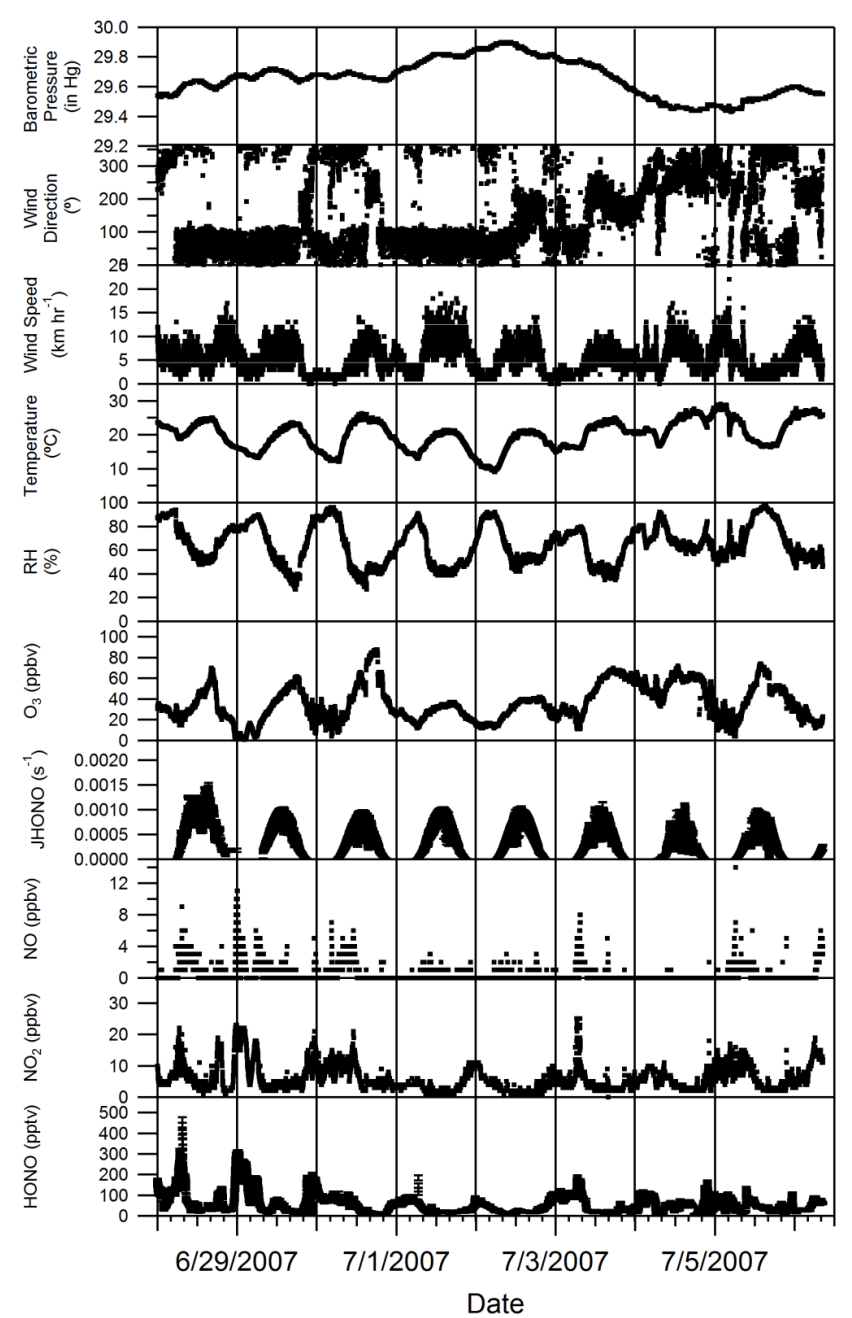

Fig. 3. Time series of the measurements of $\mathrm{HONO}, \mathrm{NO}_{2}, \mathrm{NO}$, $J_{\mathrm{HONO}}, \mathrm{O}_{3}$, relative humidity, temperature, wind speed, wind direction and barometric pressure at the Harrow measurement site from 28 June-6 July 2007.

Ratios of $\mathrm{HONO} / \mathrm{NO}_{2}$ varied between $0.5-2$ percent on this night. The increase in $\mathrm{O}_{3}$ mixing ratio during both minima in $\mathrm{HONO}$ and $\mathrm{NO}_{\mathrm{x}}$ is likely due to entrainment of air from above the boundary layer diluting the $\mathrm{HONO}$ and $\mathrm{NO}_{\mathrm{x}}$ rich air near the ground and decreasing mixing ratios of both. It is also possible that small changes in wind direction contributed to the decreases in $\mathrm{NO}_{\mathrm{x}}$ and $\mathrm{HONO}$ mixing ratio. Mixing ratios of $\mathrm{HONO}$ and $\mathrm{NO}_{2}$ began to decrease on the morning of the 29th ( 06:00 local time) as $\mathrm{O}_{3}$ mixing ratios increased, prior to the onset of photolysis, again suggesting entrainment from above the boundary layer.

\subsection{Variations in $\mathrm{HONO} / \mathrm{NO}_{2}$ ratio during the BAQS-Met Study}

The ratio of $\mathrm{HONO} / \mathrm{NO}_{2}$ over the course of the study was examined and varied between $0.06-12 \%($ mean $=1.6 \%)$ during the campaign.

The HONO/NO 2 ratio can be used as an indicator of the extent of HONO production from $\mathrm{NO}_{2}$ (Kleffmann et al., 2003). Using the $\mathrm{HONO} / \mathrm{NO}_{2}$ ratio on a night when meteorological conditions were stable, a conversion efficiency of $\mathrm{NO}_{2}$ to $\mathrm{HONO}$ could be calculated. On the night of the $23 \mathrm{rd} / 24$ th the $\mathrm{HONO} / \mathrm{NO}_{2}$ ratio increased from 0.5 to $4 \%$ over the course of a four hour period (20:00-00:00 local time) (Fig. 5). The corresponding first order conversion rate of $\mathrm{NO}_{2}$ into $\mathrm{HONO}$ was $2.43 \times 10^{-6} \mathrm{~s}^{-1}$. This rate of $\mathrm{HONO}$ formation is comparable to values calculated from data in polluted urban sites such as Berlin $\left(3.3 \times 10^{-6} \mathrm{~s}^{-1}\right)$ and $\mathrm{Mi}-$ lan $\left(5.8 \times 10^{-6} \mathrm{~s}^{-1}\right)$ (Alicke et al., 2002, Alicke et al., 2003), and will be used below in our discussions of daytime HONO sources as $k_{\text {dark }}$.

On average the ratio of $\mathrm{HONO} / \mathrm{NO}_{2}$ did not vary greatly from the day $($ mean $=1.5 \%)$, to the night $($ mean $=1.7 \%)$, thus a daytime source converting $\mathrm{NO}_{2}$ to $\mathrm{HONO}$ would have to be significantly more rapid than the night-time conversion of $\mathrm{NO}_{2}$ since the photolytic lifetime of $\mathrm{HONO}$ at midday is only $10-15 \mathrm{~min}$.

\section{2 $\mathrm{HONO} / \mathrm{NO}_{2}$ ratio as a function of wind direction}

To determine if increases in the $\mathrm{HONO} / \mathrm{NO}_{2}$ ratio were related to the direction of wind impacting the site, the ratios of $\mathrm{HONO} / \mathrm{NO}_{2}$ were examined as function of wind direction during the day and night. Figure 6 shows $\mathrm{HONO} / \mathrm{NO}_{2}$ ratios as a function of wind direction for both day and nighttime. Data for wind speeds less than $5 \mathrm{~km} \mathrm{hr}^{-1}$ were removed due to unclear wind direction during low wind conditions. Also shown on these plots is the approximate direction of the 


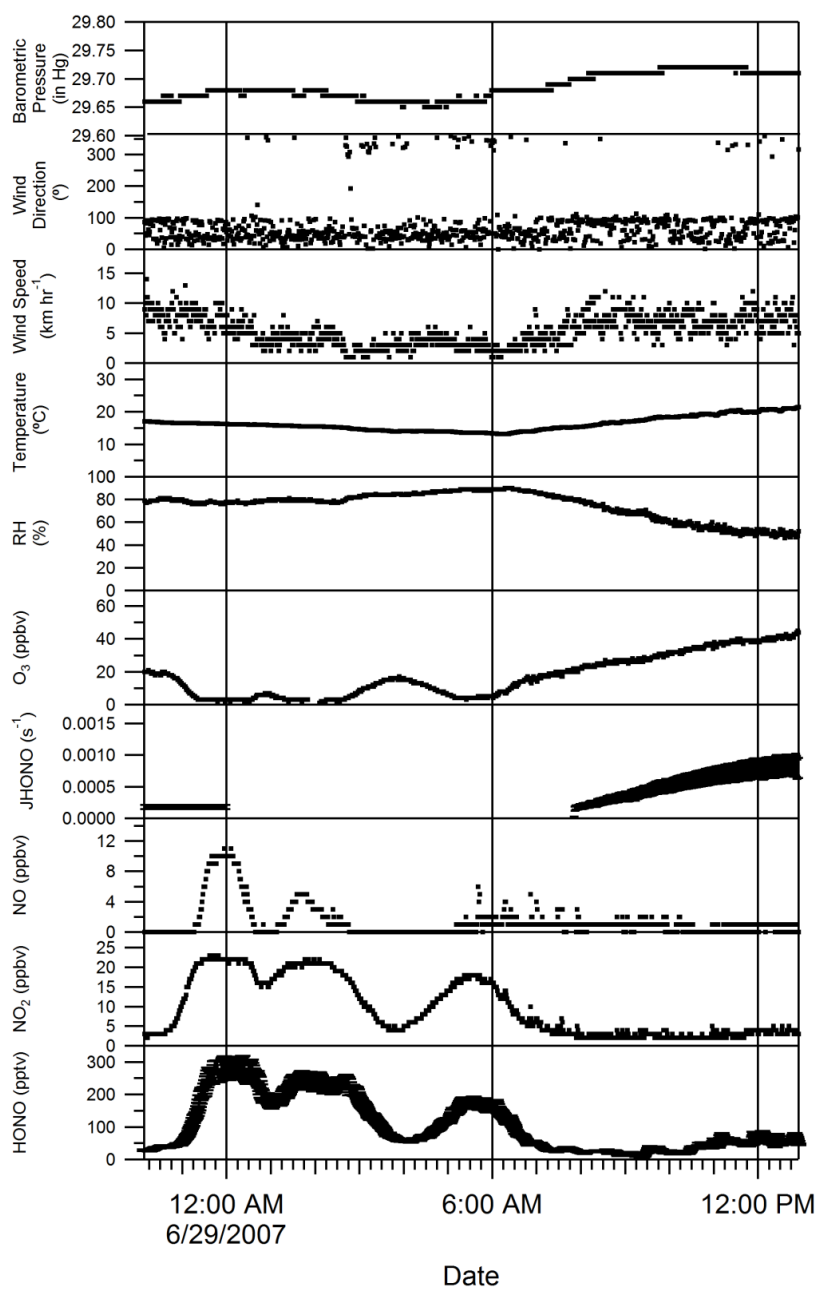

Fig. 4. Measurements of $\mathrm{HONO}, \mathrm{NO}_{2}, \mathrm{NO}, \mathrm{J}_{\mathrm{HONO}}, \mathrm{O}_{3}$, relative humidity, temperature, wind speed, wind direction and barometric pressure at the Harrow measurement site from 28-29 June 2007.

nearest source regions. During the daytime period the highest ratios are observed when winds are from between $180-270^{\circ}$. In both cases (day and night) air masses would have to travel over Lake Erie in order to reach the Harrow site. Ratios during the daytime when winds were from either the North East or South East are lower than during the night-time hours. The night-time ratio plot shows $\mathrm{HONO} / \mathrm{NO}_{2}$ ratios $>5 \%$ coming from the South and South-west. This was not often observed in the daytime data. Ratios greater than $3 \%$ are not often observed when winds are from $270-90^{\circ}$ during either the day or the night. It is possible that increased humidity in air travelling over the lake may increase the conversion of $\mathrm{NO}_{2}$ to HONO.

\subsection{Daytime production of HONO}

Daytime production of HONO was examined closely since HONO mixing ratios remained well above detection limits

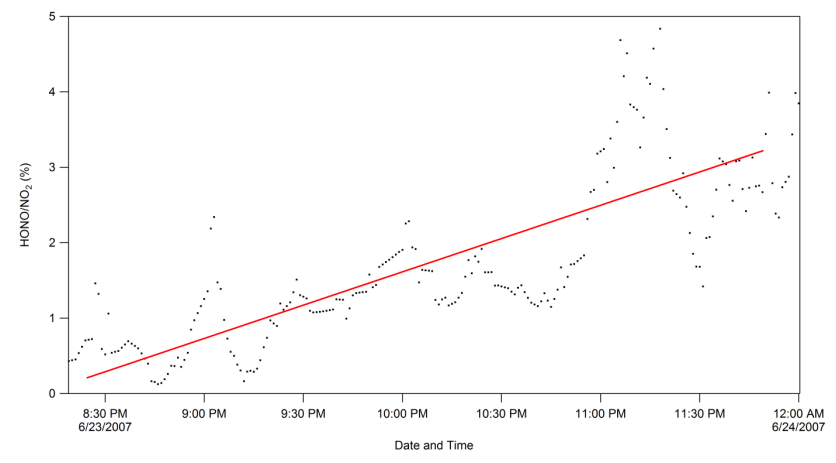

Fig. 5. Increase in $\mathrm{HONO} / \mathrm{NO}_{2}$ over the course of the evening of 23 June 2007.

during the daytime throughout the study. This cannot be explained by the first order conversion rate determined in the previous section $\left(2.43 \times 10^{-6} \mathrm{~s}^{-1}\right)$, which is roughly two orders of magnitude slower than HONO photolysis at midday. It is not believed that there any large direct emission sources of HONO in the area of the Harrow site. There was little vehicle traffic passing the site, and no large $\mathrm{NO}_{\mathrm{x}}$ emission sources in the immediate vicinity which could account for the high daytime mixing ratios.

In order to determine the amount of HONO present that could not be accounted for by known processes during the daytime hours, a photostationary state (PSS) of HONO was assumed in order to calculate expected HONO mixing ratios. The PSS is calculated with the reaction of $\mathrm{NO}$ with $\mathrm{OH}$ to form HONO (Reaction R2) and a heterogeneous formation rate equal to the night-time conversion rate

$\mathrm{NO}+\mathrm{OH}+\mathrm{M} \rightarrow \mathrm{HONO}$

of $\mathrm{NO}_{2}$ to $\mathrm{HONO}$ as sources. The destruction of $\mathrm{HONO}$ from Reaction (R1) and in the reaction with OH Reaction (R3) are the loss processes.

$\mathrm{HONO}+\mathrm{OH} \rightarrow \mathrm{NO}_{2}+\mathrm{H}_{2} \mathrm{O}$

Thus

$[\mathrm{HONO}]_{\mathrm{PSS}}=\frac{\left(k_{2}[\mathrm{NO}][\mathrm{OH}]+k_{\mathrm{dark}} \mathrm{NO}_{2}\right)}{J_{(\mathrm{HONO})}+k_{3}[\mathrm{OH}]}$

Since $\mathrm{OH}$ measurements were not available an estimate was made. A noontime $\mathrm{OH}$ value of $1 \times 10^{6} \mathrm{molec}^{-3}$ was used and mixing ratios were estimated by scaling to the diurnal variation (noontime maximum, zero at sunrise and sun-

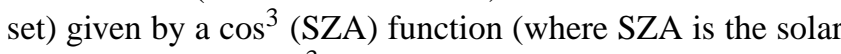
zenith angle). $\mathrm{A} \cos ^{3}$ function was chosen since its shape closely matches the profile of $\mathrm{O}^{1} \mathrm{D}$ production from $\mathrm{O}_{3}$ photolysis. Hydroxyl radical concentrations have been shown to scale well with $\mathrm{O}^{1} \mathrm{D}$ production (Rohrer and Berresheim 2006). Using these estimated $\mathrm{OH}$ values in addition to measured NO and derived $J_{\mathrm{HONO}}$ values, a HONO PSS was calculated. A HONO PSS could not be calculated when NO 

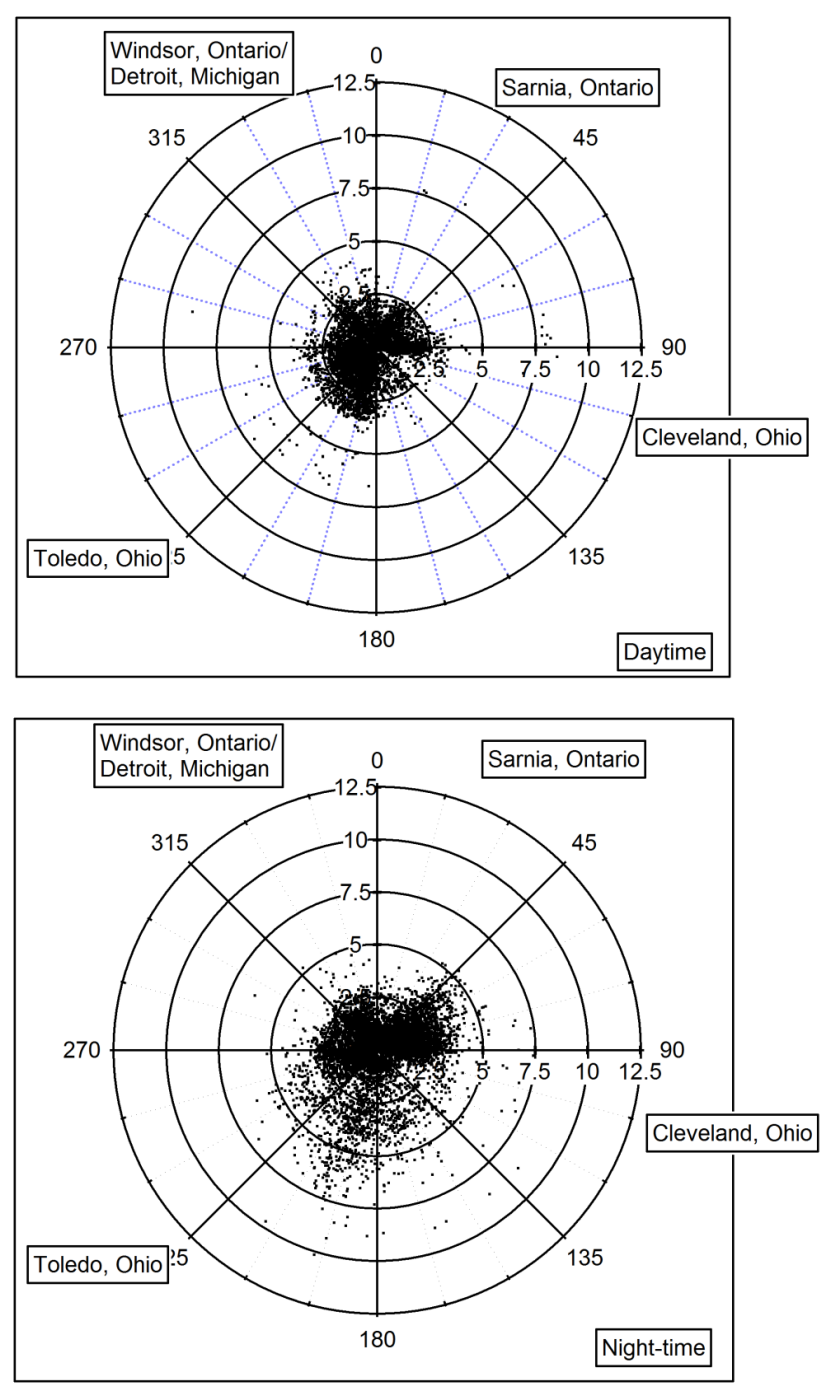

Fig. 6. Polar plots of $\mathrm{HONO} / \mathrm{NO}_{2}(\%)$ as a function of wind direction. The daytime ratios are in the left plot, the night-time ratios are in the right plot. Points where wind speeds are below $5 \mathrm{~km} / \mathrm{hr}$ have been removed.

dropped below the detection limit but this was not often a problem. While there are large uncertainties in the $\mathrm{OH}$ mixing ratio and other parameters, the calculated PSS values are very small in comparison to the measured daytime amount. The uncertainty in the HONO produced by identified sources mostly arises from the heterogeneous HONO formed and in the loss from photolysis, whose uncertainty is taken to be $20 \%$. The calculated $[\mathrm{HONO}]_{\text {PSS }}$ values were found to be only a few parts per trillion indicating that virtually all of the observed daytime HONO was formed through other sources.

Subtracting the $[\mathrm{HONO}]_{\text {PSS }}$ value from the measured daytime mixing ratios provides the amount of observed HONO in excess of that which can be accounted for by known processes. By modifying expression (1) by including an unknown HONO source and by replacing the value of
Table 2. Tabulated $R^{2}$ values for HONO production correlations.

\begin{tabular}{ll}
\hline Correlation Parameter & $R^{2}$ \\
\hline $\mathrm{NO}_{\mathrm{x}}$ & 0.12 \\
$\mathrm{NO}_{2}$ & 0.04 \\
$\mathrm{NO}$ & 0.32 \\
$J_{\mathrm{HONO}}$ & 0.62 \\
$J_{\mathrm{HONO}}\left[\mathrm{NO}_{2}\right]$ & 0.70 \\
$J_{\mathrm{HONO}}\left[\mathrm{NO}_{2}\right]\left[\mathrm{H}_{2} \mathrm{O}\right]$ & 0.76 \\
$\mathrm{O}_{3}$ & 0.16 \\
Particle Surface area Density & 0.31 \\
$J_{\mathrm{HONO}}\left[\mathrm{NO}_{2}\right]($ Particle Surface Area Density) & 0.61 \\
Relative Humidity & 0.14 \\
Wind Speed & 0.21 \\
Temperature & 0.25 \\
\hline
\end{tabular}

[HONO $]_{\text {PSS }}$ with the observed excess [HONO] and rearranging, a daytime rate for the unknown source could be calculated and the values obtained then examined in relation to other measured parameters.

Correlation coefficients between the calculated HONO production rates and various gas, aerosol and meteorological parameters are shown in Table 2. The highest values of $R^{2}$ found were with $J_{\mathrm{HONO}}, J_{\mathrm{HONO}}\left[\mathrm{NO}_{2}\right]$ and $J_{\mathrm{HONO}}\left[\mathrm{NO}_{2}\right]\left[\mathrm{H}_{2} \mathrm{O}\right]$. It was anticipated that a correlation with $J_{\mathrm{HONO}}$ would be present since the unknown source must balance photolysis, however that correlation is strengthened by the inclusion of $\mathrm{NO}_{2}$ and $\mathrm{H}_{2} \mathrm{O}$ mixing ratios.

The surface area density of aerosol particles was determined from the particle size distribution measured with a fast mobility particle sizer using the assumption of a spherical particle shape. Particles measured by the instrument were in the range of 5.5 to $560 \mathrm{~nm}$. The correlation between HONO production and particle surface area density alone $\left(R^{2}=0.31\right)$ was moderate, and not as strong as either of the correlations with $J_{\mathrm{HONO}}\left[\mathrm{NO}_{2}\right]$ or $J_{\mathrm{HONO}}\left[\mathrm{NO}_{2}\right]\left[\mathrm{H}_{2} \mathrm{O}\right]$. However the $R^{2}$ value against $J_{\mathrm{HONO}}\left[\mathrm{NO}_{2}\right.$ ][surface area density] is comparable to the highest $R^{2}$ in Table 2 (0.61 vs. 0.76) thus, while it is likely that HONO production on aerosol surface is important, it is also possible that the majority of production occurred on the ground (e.g. grass or soil), or conceivably that production is occurring homogeneously in the gas phase as has been previously suggested (Li et al., 2008). This latter possibility is discussed in the next section.

\section{Comparison with laboratory studies}

\subsection{Survey of laboratory studies}

There have been conflicting reports as to the significance of a photo-enhanced reaction of $\mathrm{NO}_{2}$ with water vapour

$\mathrm{NO}_{2}^{*}+\mathrm{H}_{2} \mathrm{O} \rightarrow \mathrm{HONO}+\mathrm{OH}$ 
In a study conducted in 1997 (Crowley and Carl 1997), $\mathrm{NO}_{2}$ was excited using radiation between $430-450 \mathrm{~nm}$ as well as at $532 \mathrm{~nm}$. OH generated by the possible reaction of $\mathrm{NO}_{2}^{*}$ with $\mathrm{H}_{2} \mathrm{O}$ was investigated using resonance fluorescence to monitor $\mathrm{OH}$. An upper limit for the rate constant of $1.2 \times 10^{-14} \mathrm{~cm}^{3} \mathrm{molec}^{-1} \mathrm{~s}^{-1}$ for Reaction (R4) was determined in that work.

A second simlar study performed in 2008 (Li et al., 2008) of the photo-enhancement used radiation at longer wavelengths, 565,590 and $612.5 \mathrm{~nm}$ and determined a rate constant for Reaction (R4) of $1.2 \times 10^{-13} \mathrm{~cm}^{3} \mathrm{molec}^{-1} \mathrm{~s}^{-1}$.

$\mathrm{Li}$ et. al., 2008 used focued laser light as the photoexcitation source and attempts to replicate the 2008 results (Carr et al., 2009) using only unfocused laser light failed to observe any $\mathrm{OH}$ production. The upper limit from (Carr et al., 2009) was a factor of 17 smaller than that of Li et al.'s 2008 result and in agreement with the earlier work (Crowley and Carl 1997). The difference in the experimental results is as yet unresolved. In this work Reaction (R4) was examined as a potential source of HONO at the Harrow site.

In order for a comparison with our calculated HONO production rates to be performed, our estimates of $J_{\mathrm{HONO}}$ were converted to estimates of $J_{\mathrm{NO}_{2}}^{*}$. Firstly, $J_{\mathrm{NO}_{2}}$ can be derived from $J_{\text {HONO }}$ using a known relationship (Kraus and Hofzumahaus 1998).

$$
J_{(\mathrm{HONO})}=0.189 \times J_{\mathrm{NO}_{2}}+8.483 \times 10^{-2} J_{\left(\mathrm{NO}_{2}\right)}^{2}
$$

Secondly, $J_{\mathrm{NO}_{2}}^{*}$ is taken to be 5 times the rate of $\mathrm{NO}_{2}$ photolysis $\left(J_{\mathrm{NO}_{2}}\right)$ based on the overall $\mathrm{NO}_{2}$ cross section and the UV/VIS spectrum of sunlight (Crowley and Carl 1997). While $J_{\mathrm{NO}_{2}}^{*}$ is not a true photolysis rate, (it is the rate for the excitation of $\mathrm{NO}_{2} \rightarrow \mathrm{NO}_{2}^{*}$ ), the $J_{\mathrm{NO}_{2}}^{*}$ nomenclature is used to remain consistent with the literature. The product of $J_{\mathrm{NO}_{2}}^{*}$ with $\left[\mathrm{NO}_{2}\right]\left[\mathrm{H}_{2} \mathrm{O}\right]$ can be compared with the daytime $\mathrm{HONO}$ production rates for the Harrow data set derived in Sect. 3.3.

\subsection{Apparent rate constants derived from BAQS-Met HONO data}

Four time periods were chosen for examination and comparison with the laboratory rate constants for (Reaction R4) to determine whether or not (Reaction R4) in the gas phase could explain the discrepancy between the measured HONO values and the much lower photostationary state values. The time periods chosen were selected for consistency of air mass during daytime. The apparent rate constants for (Reaction R4) for the chosen periods are shown in Table 3. The rate constant plots are shown in Figs. 7-10. The error value associated with the rate constant represents 1 standard deviation of the apparent rate constant value.

In each case studied the $k$ value is different, which would not be the case if a gas phase reaction, Reaction (R4), were responsible for the excess HONO production. The dominant wind directions were different each day (Table 3), and therefore the sources of $\mathrm{NO}_{2}$ and "fetch" varied accordingly. Air-

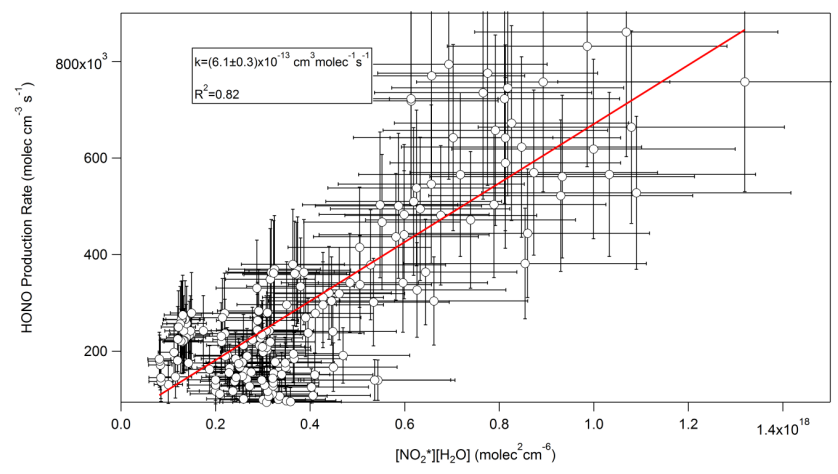

Fig. 7. Plot of measured HONO production rate with the calculated product of $\mathrm{NO}_{2}^{*}$ and water vapour for the afternoon of 21 June 2007.

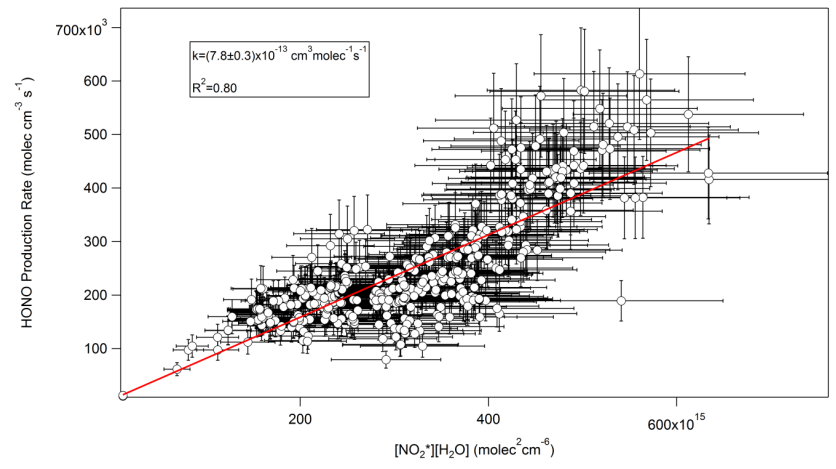

Fig. 8. Plot of measured HONO production rate with the calculated product of $\mathrm{NO}_{2}^{*}$ and water vapour for the afternoon of 24 June 2007.

mass origins during the four periods were examined using NOAA's HYSPLIT model to compute back trajectories (http: //www.arl.noaa.gov/ready/hysplit4.html) and confirm the airmass origin. During the afternoon of 21 June winds were from the North West, the direction of Detroit/Windsor. A larger apparent $k$ value was calculated for the afternoon of 24 June when winds from the South West brought air from the general direction of Toledo, Ohio. The afternoon of 24 June yielded the largest apparent $k$ value. During the morning of 30 June the wind directions were from the North East and gave the smallest apparent $k$ value. Winds were from the South West during the morning of 4 July yielding an apparent $k$ value of $(4.4 \pm 0.06) \times 10^{-13} \mathrm{~cm}^{3} \mathrm{molec}^{-1} \mathrm{~s}^{-1}$. If the highest value of the reported homogeneous rate constants of $1.2 \times 10^{-13} \mathrm{~cm}^{3} \mathrm{molec}^{-1} \mathrm{~s}^{-1}$ is assumed (Reaction R4) could still not account for the excess HONO produced since the calculated production rate is a factor of 2-6 larger.

The excess HONO could be explained by the inclusion of a surface reaction (or variety of surface reactions) as has been suggested in the literature (George et al., 2005a, Ndour et al., 2008, Stemmler et al., 2006, Stemmler et al., 2007). All of the suggested reactions include photoenhancement of HONO production from $\mathrm{NO}_{2}$ on an organic or inorganic surface. 
Table 3. List of apparent rate constants for the daytime production of HONO if assumed to occur in Reaction (R4). Also shown are dominant wind directions during the 4 selected periods of the Harrow study.

\begin{tabular}{llll}
\hline Time Period & $k\left(\mathrm{~cm}^{3} \mathrm{molec}^{-1} \mathrm{~s}^{-1}\right)$ & $R^{2}$ & Dominant Wind Direction \\
\hline All daytime data & $(4.5 \pm 3.5) \times 10^{-13}$ & 0.75 & - \\
21 July 2007 (12:00-18:00 EST) & $(6.1 \pm 0.3) \times 10^{-13}$ & 0.82 & North West \\
24 July 2007 (12:00-18:00 EST) $)$ & $(7.8 \pm 0.3) \times 10^{-13}$ & 0.80 & South West \\
30 June 2007 (06:00-12:00 EST) & $(2.9 \pm 0.07) \times 10^{-13}$ & 0.90 & North East \\
4 July 2007 (06:00-12:00 EST) & $(4.4 \pm 0.06) \times 10^{-13}$ & 0.97 & South West \\
\hline
\end{tabular}
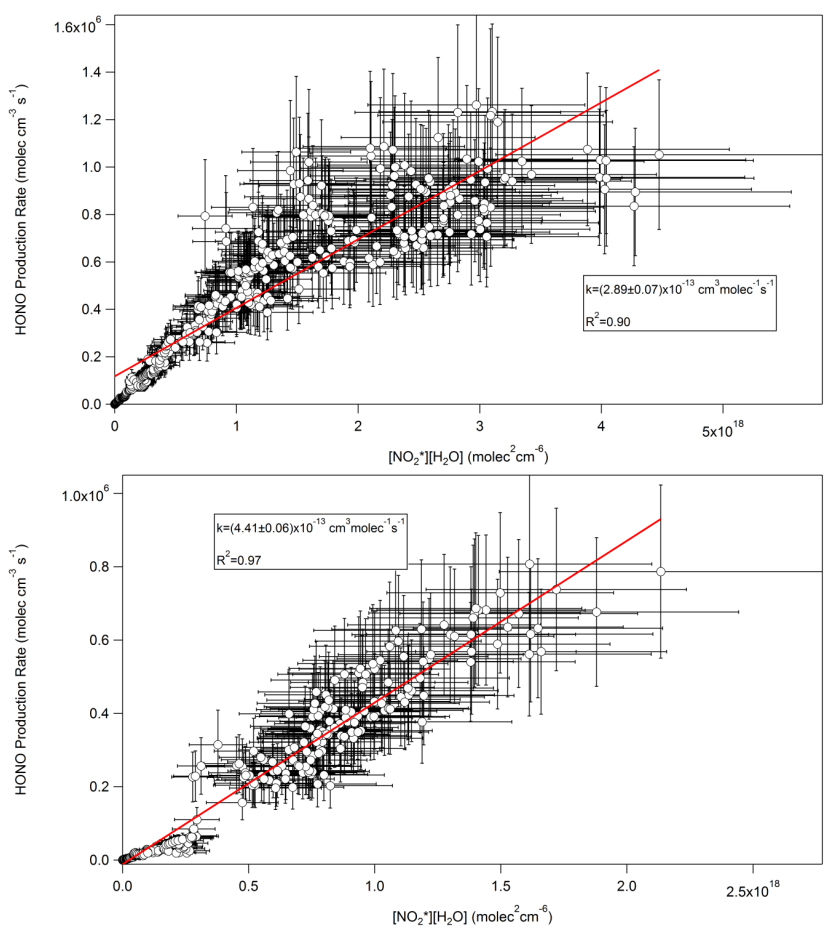

Fig. 9. (a) Plot of measured HONO production rate with calculated product of $\mathrm{NO}_{2}^{*}$ and water vapour for the morning 30 June 2007 (b) Plot of measured $\mathrm{HONO}$ production rate with the calculated product of $\mathrm{NO}_{2}^{*}$ and water vapour for 4 July 2007.

Taken with the highest gas phase rate suggested, our data impliy $50-85 \%$ of the HONO is present as a result of surface reactions; if the lower rate for Reaction (R4) is accepted the gas phase process is negligible.

In order to determine whether there was any enhancement over water the case of the afternoon of 24 June was examined. With windspeeds lower than $10 \mathrm{~km} \mathrm{hr}^{-1}$ HONO could not be brought from the lake to the site within its midday lifetime of 10 to $20 \mathrm{~min}$. It is unlikely that a significant fraction of the measured HONO could be produced over the lake near midday when $J_{\mathrm{HONO}}$ is highest. Near midday the HONO appears to be produced between the measurement site and the shoreline on ground surfaces and/or on particles.

\section{Summary and conclusions}

A custom long path absorption photometer (LOPAP) was successfully deployed to measure HONO in Southern Ontario. The instrument provided excellent sensitivity ( $3 \sigma$ detection limit=5 pptv) and response time $(5 \mathrm{~min})$ for making high quality HONO measurements. The measurements of HONO at the Harrow site during BAQS-Met show high mixing ratios of daytime HONO present with a mean value of 61 pptv. These larger than anticipated daytime mixing ratios imply that HONO may play a larger role in the midday $\mathrm{OH}$ budget than originally thought. A night-time compensation point for heterogenous production and deposition of HONO consistent with the work of Stutz et al. (2002) was also observed when stable meterological conditions were present. Since the apparent values of a rate constant describing HONO production in (Reaction R4) are large and variable it is likely HONO produced solely through a simple gas phase process is unimportant or negligible. Many laboratory studies have suggested efficient heterogeneous conversion of $\mathrm{NO}_{2}$ on surfaces, enhanced by photo-excitation, which appears to be consistent with the Harrow data.

Acknowledgements. The authors would like to thank Greg Evans from the University of Toronto and Nick Karellas from the Ontario Ministry of the Environment for providing measurements of particle surface area densities, meteorological data, and measurements of $\mathrm{O}_{3}$ and $\mathrm{NO}_{\mathrm{x}}$ from the Harrow site as well as Agriculture and Agri-Food Canada for the use of the site.

Edited by: J. W. Bottenheim

\section{References}

Acker, K., Möller, D., Wieprecht, W., Meixner, F. X., Bohn, B., Gilge, S., Plass-Dülmer, C., and Berresheim, H.: Strong daytime production of $\mathrm{OH}$ from $\mathrm{HNO} 2$ at a rural mountain site, Geophys. Res. Lett., 33, L02809, doi:10.1029/2005GL024643, 2006.

Alicke, B., Geyer, A., Hofzumahaus, A., Holland, F., Konrad, S., Patz, H. W., Schafer, J., Stutz, J., Volz-Thomas, A., and Platt, U.: OH formation by HONO photolysis during the BERLIOZ experiment, J. Geophys. Res., 108, 8247-8264, 2003. 
Alicke, B., Platt, U., and Stutz, J.: Impact of nitrous acid photolysis on the total hydroxyl radical budget during the Limitation of Oxidant Production/Pianura Padana Produzione di Ozono study in Milan, J. Geophys. Res., 107, 8196-8213, 2002.

Bejan, I., Abd-el-Aal, Y., Barnes, I., Benter, T., Bohn, B., Wiesen, P., and Kleffmann, J.: The photolysis of ortho-nitrophenols: a new gas phase source of HONO, Phys. Chem. Chem. Phys., 8, 2028-2035, 2006.

Carr, S., Heard, D. E., and Blitz, M. A.: Comment on Atmospheric Hydroxyl Radical Production from Electronically Excited $\mathrm{NO}_{2}$ and $\mathrm{H}_{2} \mathrm{O}$, Science, 324, 336b, 2009.

Crowley, J. N. and Carl, S. A.: OH Formation in the Photoexcitation of $\mathrm{NO}_{2}$ beyond the Dissociation Threshold in the Presence of Water Vapor, J Phys. Chem. A, 101, 4178-4184, 1997.

George, C., Strekowski, R. S., Kleffmann, J., Stemmler, K., and Ammann, M.: Photoenhanced uptake of gaseous $\mathrm{NO}_{2}$ on solid organic compounds: a photochemical source of HONO?, Faraday Discuss., 130, 195-210, 2005.

Harris, G. W., Carter, W. P. L., Winer, A. M., Pitts, J. N., Platt, U., and Perner, D.: Observations of nitrous acid in the Los Angeles atmosphere and implications for predictions of ozone-precursor relationships, Environ. Sci. Technol., 16, 414-419, 1982.

Heland, J., Kleffmann, J., Kurtenbach, R., and Wiesen, P.: A New Instrument To Measure Gaseous Nitrous Acid (HONO) in the Atmosphere, Environ. Sci. Technol., 35, 3207-3212, 2001.

Kleffmann, J.: Daytime sources of nitrous acid (HONO) in the atmospheric boundary layer, Chemphyschem, 8, 1137-1144, 2007.

Kleffmann, J., Gavriloaiei, T., Hofzumahaus, A., Holland, F., Koppmann, R., Rupp, L., Schlosser, E., Siese, M. and Wahner, A.: Daytime formation of nitrous acid: A major source of $\mathrm{OH}$ radicals in A forest, Geophys. Res. Lett., 32, L05818, doi:10.1029/2005GL022524, 2005.

Kleffmann, J., Heland, J., Kurtenbach, R., Lörzer, J., and Wiesen, P.: A New Instrument (LOPAP) for the Measurement of Nitrous Acid (HONO), Environ. Sci. Pollut. Res., 48-54, 2002.

Kleffmann, J., Kurtenbach, R., Lörzer, J., Wiesen, P., Kalthoff, N., Vogel, B., and Vogel, H.: Measured and simulated vertical profiles of nitrous acid-Part I: Field Measurements, Atmos. Environ., 37, 2949-2955, 2003.
Kraus, A. and Hofzumahaus, A.: Field Measurements of Atmospheric Photolysis Frequencies for $\mathrm{O}_{3}, \mathrm{NO}_{2}, \mathrm{HCHO}, \mathrm{CH}_{3} \mathrm{CHO}$, $\mathrm{H}_{2} \mathrm{O}_{2}$, and $\mathrm{HONO}$ by UV Spectroradiometry, J. Atmos. Chem., 31, 161-180, 1998.

Li, S., Matthews, J., and Sinha, A.: Atmospheric Hydroxyl Radical Production from Electronically Excited $\mathrm{NO}_{2}$ and $\mathrm{H}_{2} \mathrm{O}$, Science, 319, 1657-1660, 2008.

Ndour, M., D’Anna, B., George, C., Ka, O., Balkanski, Y., Kleffmann, J., Stemmler, K. and Ammann, M.: Photoenhanced uptake of $\mathrm{NO}_{2}$ on mineral dust: Laboratory experiments and model simulations, Geophys. Res. Lett., 35, L05812, doi:10.1029/2007GL032006, 2008.

Platt, U., Perner, D., Harris, G. W., Winer, A. M. and Pitts, J. N.: Observations of nitrous acid in an urban atmosphere by differential optical absorption, Nature, 285, 312-314, 1980.

Rohrer, F. and Berresheim, H.: Strong correlation between levels of tropospheric hydroxyl radicals and solar ultraviolet radiation, Nature, 442, 184-187, 2006.

Stemmler, K., Ammann, M., Donders, C., Kleffmann, J., and George, C.: Photosensitized reduction of nitrogen dioxide on humic acid as a source of nitrous acid, Nature, 440, 195-198, 2006.

Stemmler, K., Ndour, M., Elshorbany, Y., Kleffmann, J., D’Anna, B., George, C., Bohn, B., and Ammann, M.: Light induced conversion of nitrogen dioxide into nitrous acid on submicron humic acid aerosol, Atmos. Chem. Phys., 7, 4237-4248, doi:10.5194/acp-7-4237-2007, 2007.

Stutz, J., Alicke, B., and Neftel, A.: Nitrous acid formation in the urban atmosphere: Gradient measurements of $\mathrm{NO}_{2}$ and $\mathrm{HONO}$ over grass in Milan, Italy, J. Geophys. Res., 107, 8192-8208, 2002.

Wall, K. J., Schiller, C. L., and Harris, G. W.: Measurements of the HONO photodissociation constant, J. Atmos. Chem., 55, 31-54, 2006. 